\title{
O ESTADO NOVO E AS CRÍTICAS A MACHADO DE ASSIS NA PRIMEIRA METADE DOS ANOS 1940
}

\author{
Thiago Mio Salla \\ Universidade de São Paulo \\ São Paulo (SP), Brasil
}

\begin{abstract}
Resumo: Este artigo tem como objetivo analisar o tratamento conferido pelo Estado Novo brasileiro (1937-1945) a Machado de Assis, depois das celebrações oficiais do centenário do autor de Dom Casmurro em 1939. Se, no ano da efeméride, o governo se empenhou em alçar o romancista à condição de maior escritor brasileiro, no início dos anos 1940, no âmbito do Departamento de Imprensa e Propaganda (DIP), o tom passa a ser outro: num contexto de prevalência de certo caráter social e documental da obra de arte, o próprio Getúlio Vargas, o ideólogo Cassiano Ricardo e os principais periódicos estadonovistas fazem menção ao suposto absenteísmo e à falta de "cor local" do fundador da Academia Brasileira de Letras.
\end{abstract}

Palavras-chave: Machado de Assis; Cassiano Ricardo; Estado Novo; Getúlio Vargas; Departamento de Imprensa e Propaganda.

\section{The Estado Novo and the criticism to Machado de Assis in the first half of the 1940's}

\begin{abstract}
This article aims to analyse the treatment given by the Brazilian Estado Novo (1937-1945) to Machado de Assis, after the official celebrations of the birth centenary of the author of Dom Casmurro, in 1939. If in the year of Machado's centennial the government raised him to the status of the greatest Brazilian writer, in the early 1940s, under the Department of Press and Propaganda (DIP), the tone was different: in the context of the prevalence of social and documentary conceptions of art, Getúlio Vargas himself, the ideologue Cassiano Ricardo and major estadonovista journals criticized the alleged absenteeism and lack of "local color" in the work of the founder of Brazilian Academy of Letters.
\end{abstract}

Keywords: Machado de Assis; Cassiano Ricardo; Estado Novo; Getúlio Vargas; Department of Press and Propaganda.

1939, ano do centenário de nascimento de Machado de Assis. Em plena vigência do Estado Novo, o poder central organiza uma série de iniciativas que têm o 
fito de celebrar o aniversário do autor de Dom Casmurro, bem como alçá-lo à condição de "mito nacional". Entre tais empreendimentos estatais, destaque para a exposição "Machado de Assis", organizada pelo Instituto Nacional do Livro (INL), em cuja inauguração esteve presente o próprio Getúlio Vargas; e para o filme Um apólogo Machado de Assis, de Humberto Mauro, realizado pelo Instituto Nacional do Cinema Educativo (INCE), órgão que, assim como o INL, vinculava-se ao Ministério da Educação e Saúde, comandado por Gustavo Capanema. As homenagens oficiais, contudo, não param por aí: retratos do romancista são inaugurados em escolas do Rio de Janeiro e o busto dele cunhado nas moedas de 500 réis, "numa associação inequívoca do escritor ao nacionalismo oficial do Estado Novo". ${ }^{1}$

A princípio, tais ações teriam contribuído para a consagração de Machado de Assis como o grande artista brasileiro durante a ditadura varguista. ${ }^{2} \mathrm{O}$ processo de monumentalização conduzido pelo regime orientava-se, sobretudo, pelo louvor à trajetória social ascendente descrita pelo romancista: apesar de lutar contra um extenso rol de dificuldades (era negro, órfão, pobre, epilético e gago), ele teria saído do Morro do Livramento e chegado à presidência da Academia Brasileira de Letras (ABL). ${ }^{3}$ Nesse sentido, numa leitura que se ajustava ao ideário trabalhista do governo, a biografia de Machado atestaria, de modo exemplar, que seria possível vencer por meio do estudo e

\footnotetext{
${ }^{1}$ GUIMARÃES, Hélio de Seixas. "Um apólogo - Machado de Assis" - do escritor singular ao brasileiro exemplar. Machado de Assis em linha n. 8. Rio de Janeiro; São Paulo, dez. 2011. Disponível em: <http://machadodeassis.net/revista/numero08/ rev_num08_artigo06.pdf >. Acesso em: 01.06. 2012. De acordo com o decreto-lei 1.360-A, de 21 de julho de 1939, que dispunha sobre as comemorações do primeiro centenário de Machado de Assis, o governo ainda se responsabilizaria, entre outras ações, pela edição crítica das obras completas de Machado e por "uma edição de luxo e ilustrada de três volumes de Machado de Assis, sendo um de contos, um de poesias e outro constituído pelo romance Dom Casmurro" (BRASIL. Presidência da República. Coleção das Leis da República dos Estados Unidos do Brasil - Atos do Poder Executivo. 8 vols. Rio de Janeiro: Imprensa Nacional, 1939, vol. 4, p. 289).

${ }^{2}$ FERREIRA, Gabriela Manduca. A crítica machadiana durante o Estado Novo. Dissertação (mestrado em Literatura Brasileira), Faculdade de Filosofia, Letras e Ciências Humanas, Universidade de São Paulo. São Paulo, 2011. p. 11. Além de acompanhar a repercussão na imprensa das homenagens governamentais feitas a Machado em 1939, a pesquisadora faz um exame minucioso da produção crítica de importantes machadianos (Lúcia Miguel Pereira, Astrojildo Pereira, Augusto Meyer e Eugênio Gomes), procurando investigar em que medida essas figuras, em tal enquadramento histórico, teriam contribuído ou não para a consagração do autor de Dom Casmurro.
}

${ }^{3}$ Idem, p. 113. 
do trabalho. Não por acaso, passava-se a colar ao escritor o epíteto de "grande operário das letras". 4

Porém, quando se examina o tratamento conferido pelo Estado Novo a Machado para além da efeméride do centenário de nascimento do artista e das homenagens circunstanciais feitas a ele pelo Ministério da Educação e Saúde, em 1939, ${ }^{5}$ a consagração cede lugar a certa dose de rebaixamento. Na primeira metade dos anos 1940, algumas manifestações, tais como o discurso de posse de Getúlio Vargas na ABL, a invectiva de Cassiano Ricardo contra o autor de Quincas Borba, em Marcha para Oeste (1940), bem como as abordagens da figura e da obra de Machado nos principais periódicos estadonovistas destinados à área cultural, permitem divisar outra imagem do escritor, também difundida pelo regime de 1937: em chave oposta, consoante com leituras do começo do século XX que ainda tomavam o romancista carioca como "anatoliano", castiço e filosofante, ${ }^{6}$ ou mesmo de acordo com resquícios de percepções críticas oitocentistas, ${ }^{7}$ ainda ele era caracterizado por sua aparente frieza, pessimismo e desconexão em relação às matérias brasileiras.

Em meio a essas atitudes opostas, deve-se considerar que, enquanto as homenagens a Machado foram patrocinadas pelo Ministério da Educação e Saúde (MES), as críticas ao romancista deram-se, sobretudo, no âmbito do Departamento de Imprensa e Propaganda (DIP). No projeto estadonovista, tais órgãos apresentavam diferentes concepções do que seria a política cultural do regime, bem como atuavam de modo diverso. O MES, que era dirigido por Gustavo Capanema e contava em seu estafe com Carlos Drummond de Andrade e Rodrigo Melo Franco, entre outros,

\footnotetext{
${ }^{4}$ GUIMARÃES, Hélio de Seixas. "Um apólogo - Machado de Assis" - do escritor singular ao brasileiro exemplar, cit.

${ }^{5}$ Durante a vigência do Estado Novo (1937-1945), o caráter episódico das atenções voltadas a Machado no ano de 1939 pode ser ilustrado pela quantidade de artigos e obras incluídos por J. Galante de Sousa no livro Fontes para o estudo de Machado de Assis, entre 1937 e 1945. Se em 1939 são catalogadas 557 referências ao autor, em 1937, tem-se apenas 32; em 1938, 50; em 1940, 86; em 1941, 35; em 1942, 20; em 1943, 23; em 1944, 34; e em 1945, 16.

${ }^{6}$ CANDIDO, Antonio. Esquema de Machado de Assis. In: Vários escritos. São Paulo; Rio de Janeiro: Duas Cidades; Ouro sobre Azul, 2004. p. 19.

${ }^{7}$ Destaque para certos postulados da crítica de Silvio Romero que rebaixavam o aparente caráter apolítico e estrangeirado do autor de Dom Casmurro, cuja obra seria supostamente marcada pela falta de exaltação patriótica e pelo baixo investimento na pintura da natureza local. Cf. GUIMARÃES, Hélio de Seixas. O escritor que nos lê. In: ; SACHETTA, Vladimir (Orgs.). Cadernos de Literatura Brasileira, n. 23 e 24. São Paulo: Instituto Moreira Salles, 2008. p. 277.
} 
responsabilizava-se pelo ensino formal e preocupava-se fundamentalmente com a cultura erudita. O DIP, encabeçado por Lourival Fontes, com o suporte de intelectuais da vertente conservadora do modernismo, tais como Cassiano Ricardo e Menotti del Picchia, voltava-se para um público mais amplo e, mediante o controle dos meios de comunicação e o investimento em canais oficiais de propaganda, procurava orientar as manifestações da cultura popular e, assim, construir e dirigir o arcabouço conceitual que dava suporte ao Estado Novo. ${ }^{8}$

É no âmbito do DIP, ${ }^{9}$ por meio de seus diferentes agentes (com destaque para a figura de Cassiano Ricardo) e de suas publicações voltadas à área cultural (o suplemento Autores e Livros e a revista Cultura Política), que se cristalizam e se difundem os postulados governamentais referentes à literatura. Tais diretrizes ratificam como critérios de autenticidade a ênfase no espaço (região) e no tempo (história), num contexto em que o estudo da realidade brasileira, em chave documental, figurava como tema obrigatório, lema político e artístico, uma espécie de fonte de todos os sentidos. ${ }^{10}$ Diante de tal cenário, a figura de Machado, antes glorificada oficialmente por ocasião de seu centenário, passa a ser avaliada criticamente, pois não se encaixava na proposta nacionalista de engajamento intelectual propagandeada pelo Estado que se dizia novo.

\section{Getúlio e a Casa de Machado de Assis}

\footnotetext{
${ }^{8}$ VELLOSO, Mônica Pimenta. Os intelectuais e a política cultural do Estado Novo. In: FERREIRA, Jorge e DELGADO, Lucilia de Almeida Neves (Orgs.). O tempo do nacional-estatismo: do início da década de 1930 ao apogeu do Estado Novo. (O Brasil republicano; v. 2). Rio de Janeiro: Civilização Brasileira, 2007. p.149.

${ }^{9}$ O DIP foi criado em dezembro de 1939, pouco depois das comemorações do centenário de Machado. Tratava-se de um momento de ampliação do aparelho estatal e de concentração do poder na figura de Getúlio. Não por acaso, tal órgão se vinculava diretamente ao gabinete da presidência da República. Essa proximidade ao Executivo, no contexto de um Estado autoritário, já dá mostra de seu caráter estratégico. Cf. GOULART, Silvana. Sob a verdade oficial: ideologia, propaganda e censura no Estado Novo. São Paulo; Brasília: Marco Zero; Programa Nacional do Centenário da República e Bicentenário da Inconfidência Mineira; MCT/CNPq, 1990. p. 47-76.

${ }^{10}$ Graciliano Ramos, de maneira irônica, explicita essa ideia em sua Pequena História da República. "Os homens de 1930 não tinham um programa. E justificaram-se. Como poderiam arranjar isso? Importar? Que é que deviam importar? [...] Assim, os revolucionários deram uma explicação razoável ao público: tencionavam firmar-se na realidade brasileira. E como essa realidade tudo podia comportar, houve aqui um saco de gatos: inimigos ferozes se juntaram, ideias contraditórias tentaram harmonizar-se" (RAMOS, Graciliano. Alexandre e outros heróis. Rio de Janeiro: Record, 2003. p.188).
} 
Em seu discurso de posse na Academia Brasileira de Letras (ABL), em 1943, Getúlio Vargas sinalizava para a aparente deformação lógica que teria governado o pensamento brasileiro até 1930, quando administradores e intelectuais se encontravam supostamente divorciados. Para o presidente, como decorrência desse cenário, a instituição fundada por Machado de Assis reservava suas cadeiras apenas àqueles que tratassem, de forma desinteressada, das "coisas do espírito", mantendo-se distante dos problemas nacionais:

A Casa de Machado de Assis parecia reservada, nas minhas reflexões, aos homens votados à criação artística e ao estudo desinteressado dos problemas culturais. Não a considerava gleba apropriada ao rude amanho dos agricultores, mas terreno escolhido e tratado, onde os jardineiros operam milagres de beleza e colorido. ${ }^{11}$

De acordo com o jogo de imagens utilizadas pelo presidente, os "jardineiros" corresponderiam aos chamados "homens de pensamento", às inteligências cultas, que olhariam para a vida de forma fria e distanciada, em termos de "categoria filosófica", procurando beleza e colorido, ao mesmo tempo em que recusavam o contato direto com a terra, com a "gleba" nacional. Os agricultores, pelo contrário, seriam os "homens de ação", ou seja, aqueles voltados ao estudo da realidade do país por meio das artes e de atividades práticas. Portanto, não se furtavam a revolver o solo, em seu rude amanho, com o objetivo de produzirem obras destinadas à recuperação das raízes brasileiras.

Ao equiparar "jardineiros" e "agricultores", Getúlio sublinhava que a Academia não poderia manter-se alheia à vida nacional. Aos olhos do chefe do governo, ela adquirira, sobretudo durante o decênio de 1930, um papel mais ativo sobre o conjunto da realidade brasileira, em seus múltiplos aspectos. Seu objetivo passara a ser o de coordenar tendências, ideias e valores, além de "elevar a vida intelectual do país a um plano superior, imprimindo-lhe direção construtiva, força e equilíbrio criador". ${ }^{12}$ Nesse sentido, Vargas afirmava que a tarefa de engrandecimento da cultura a cargo da instituição passava, inevitavelmente, pelo estudo e pela solução dos grandes problemas

\footnotetext{
${ }^{11}$ VARGAS, Getúlio. A nova política do Brasil. 11 v. Rio de Janeiro: Livraria José Olympio Editora, v. 10, 1944. p. 221.

${ }^{12}$ Idem, p. 223-224.
} 
da nacionalidade. Por tal perspectiva, entendia-se que os atributos e qualidades dos "homens de pensamento" deveriam ser utilizados para o enfrentamento e a solvência das tarefas desempenhadas pelos aludidos "homens de ação", sobretudo por aqueles pertencentes ao aparelho do Estado. ${ }^{13}$ Ao mesmo tempo, atrelava-se a arte a certo propósito nacionalista, e o escritor, tal como o agricultor aludido anteriormente, deveria dedicar-se ao Brasil, revolvendo o solo pátrio e colhendo os frutos (obras) a partir deste trabalho. A literatura, portanto, passava a ser sinônimo de nação.

Não por acaso, o discurso de Getúlio aludia ao processo mais amplo de construção e reaparelhamento do Estado, sob sua batuta, que tomou corpo no Brasil entre os anos 1930 e 1940. Como se sabe, a montagem e a viabilização de tal máquina administrativa "justificou a demanda de especialistas, envolveu intelectuais de várias áreas e deu chance a homens ilustrados e propositivos". ${ }^{14}$ Desiludidos com o regime republicano, eles teriam sido atraídos pelo projeto intervencionista e modernizador do governo de Getúlio, na medida em que este se mostrava pautado, aparentemente, por "racionalidade, planejamento, combate ao regionalismo, às oligarquias e ao mandonismo local". ${ }^{15} \mathrm{O}$ discurso reinante era de que o país pedia uma política nacional de Estado que levasse a modernidade a setores importantes da vida social como saúde, educação, cultura, artes, patrimônio histórico, entre outros.

Conforme sublinha Pécaut, tal fortalecimento do Estado teria ocorrido pari passu à elaboração de uma cultura política que subsidiava o direcionamento da intelectualidade à ação. Para além do caráter mecânico e individual da noção de interesse ${ }^{16}$ o sociólogo francês prefere encarar a dimensão complexa do engajamento da

13 A entrada de Vargas na Academia, orquestrada por Cassiano Ricardo, seria, simbolicamente, a personificação de tal simbiose entre "homens de pensamento" e "homens de ação" (JOHNSON, Randal. A dinâmica do campo literário brasileiro (1930-1945). Revista USP, n. 26. São Paulo: USP,1995. p. 168).

14 BOMENY, Helena. Infidelidades eletivas: intelectuais e política. In: Capanema: intelectuais e política. Rio de Janeiro: Editora FGV, 2001. p. 17. (Org). Constelação

${ }^{15}$ Idem, p. 21.

${ }^{16}$ Em específico, Pécaut questiona a noção de "interesse" utilizada por Miceli, em Intelectuais e a classe dirigente no Brasil (1920-45), para justificar o engajamento intelectual no período. Segundo o sociólogo francês, tal conceito não poderia se restringir a simples busca por um emprego público, pois deveria ser encarado para além de um prisma meramente personalista. Por seu turno, Miceli considera a busca por postos de trabalho no aparato estatal como a principal estratégia utilizada por membro de famílias oligárquicas decadentes para preservar a posição de elite dirigente, num contexto de perda de status e desterritorialização pessoal, em decorrência da rarefação das carreiras tradicionais, da ampliação do mercado de bens culturais, da necessidade de profissionalização do fazer intelectual e de fortalecimento do Estado. Para Miceli, Pécaut, ao concentrar suas atenções nas motivações políticas e culturais da 
intelligentsia como resultado da mescla entre as modalidades de autenticação dos campos político e cultural que estavam em vias de se consolidar naquele momento histórico específico e, em função disso, entrecruzavam-se a todo o momento num processo amplo de recriação institucional. Nesse sentido, a participação intelectual no aparelho de Estado não teria sido ditada pela simples conveniência, mas sim pela "vontade de contribuir para fundamentar o cultural e o político de uma forma diferente", ${ }^{17}$ depois das desilusões com a Primeira República.

Em certo sentido, o próprio contexto brasileiro, pautado pela incipiência e pelo caráter pouco diferençado das instituições culturais, levaria os intelectuais a reorientar seus investimentos e projetos na direção governamental. Paralelamente, nesse jogo simultâneo de engajamentos, apagamentos e apropriações, o Estado acabaria por incorporar, mesmo à revelia de certos atores, muitas das propostas modernistas (desbastadas de suas rebarbas) que privilegiavam a organicidade e a incorporação de elementos nacionais. De modo geral, observa-se o desdobramento de um processo amplo de homogeneização e naturalização de um passado conscientemente selecionado, tendo em vista o construto da "legitimidade emocional", ${ }^{18}$ norteadora do nacionalismo propagandeado pela ditadura varguista.

Nesse sentido, pode-se entender que Getúlio realizava, no seu discurso de posse na $\mathrm{ABL}$, uma crítica indireta à postura do fundador da instituição, sobretudo no que diz respeito ao tratamento dispensado por Machado de Assis às matérias brasileiras e ao papel dos intelectuais. Conforme explica o então presidente da República, a entidade fundada pelo autor de Quincas Borba nascera sob a invocação da Academia Francesa, ou seja, submissa a influências externas. Além disso, colocava-se preferencialmente como "refúgio" e "repouso amável" a "espíritos serenos", que apenas observavam com "imparcial frieza" os acontecimentos atuais. O próprio Machado, em discurso proferido na sessão de encerramento das atividades da ABL em 1897, fazia questão de ressaltar que "nascida entre graves cuidados de ordem pública, a Academia

intelectualidade (vista enquanto categoria social específica, "sem vínculos"), pecaria por deixar de lado condicionantes classistas, tais como os laços que ligavam os intelectuais aos grupos dominantes e os interesses corporativos que foram se consolidando em meio às reformas empreendidas pelo regime varguista (MICELI, Sérgio. Intelectuais à brasileira. São Paulo: Companhia das Letras, 2001. p. 375).

${ }^{17}$ PÉCAUT, Daniel. Intelectuais e a política no Brasil. São Paulo: Ática, 1990. p. 21-22.

${ }^{18}$ ANDERSON, Benedict. Comunidades imaginadas. São Paulo: Companhia das Letras, 2008. p. 30. 
Brasileira de Letras tem de ser o que são as associações análogas: uma torre de marfim, onde se acolham espíritos literários, com a única preocupação literária [...]". ${ }^{19}$ Em sentido oposto, Vargas reivindicava um contato "íntimo" e "direto" entre a intelectualidade e os problemas brasileiros, sem fugas contemplativas ou retiros em asilos seguros. Por sua perspectiva, era preciso que os homens de letras deixassem o isolamento e participassem de maneira viva e intensa da construção da nacionalidade.

\section{Machado de Assis x Euclides da Cunha}

$\mathrm{Na}$ concepção getulista, se Machado figurava como um romancista afeito, preferencialmente, às coisas do espírito, olhando para as matérias nacionais com distância e desinteresse, Euclides da Cunha, por outro lado, seria tomado como seu contraponto. Para o presidente, o autor de Os sertões colocava-se como uma espécie de síntese das categorias "homens de pensamento" e "homens de ação". Numa entrevista compilada em A nova política do Brasil, Getúlio se refere a Euclides como "escritor da terra", artista em cuja obra os contemporâneos e os vindouros recolheriam "a mensagem da raça ou da Pátria, como testemunho da sua inquietação, dos seus anseios ou esperanças". ${ }^{20}$ Em outras palavras, a literatura euclidiana destacava-se aos olhos de Vargas por sua aparente função social e política, dentro de certa perspectiva a um só tempo utilitarista e nacionalista.

A oposição entre Euclides e Machado, como personificações de duas vertentes antagônicas da literatura nacional, ${ }^{21}$ torna-se mais explícita no pensamento de Cassiano

\footnotetext{
19 ASSIS, Machado de. Academia Brasileira de Letras (2). In: HENRIQUES, Claudio Cezar. Atas da Academia Brasileira de Letras: Presidência de Machado de Assis (1896-1908). Rio de Janeiro: ABL, 2001. p. 199.

${ }^{20}$ Ao responder à questão "Dos escritores nacionais, a quem V. Exa. confere o caráter mais representativo?", Getúlio, além de Euclides, destaca a figura de Gonçalves Dias, descrito como o poeta da raça. VARGAS, Getúlio. A nova política do Brasil. 11v. Rio de Janeiro: Livraria José Olympio Editora. v. 6, 1940. p. 239.

${ }^{21}$ Essa parece ser uma tópica do discurso crítico da época. Em artigo intitulado "Vida literária - Euclides e Machado", publicado em O Jornal (Rio de Janeiro, 5 e 12 mar. 1939), Alceu Amoroso Lima pontuava que, enquanto o autor de Contrastes e confrontos simbolizava, entre outros aspectos, o sertão, a terra, a voz do povo e o espírito científico, o romancista de Dom Casmurro, por sua vez, representava o litoral, o homem, a voz da elite e o espírito literário. Em A cultura brasileira (1943), Fernando Azevedo não deixava de pontuar que a dicotomia entre os dois escritores refletiria as duas facetas do espírito nacional, "uma voltada para o Atlântico, a outra para os sertões" (AZEVEDO, Fernando. A cultura brasileira. Rio de Janeiro; Brasília: Editora da UFRJ; Editora da UnB, 1996. p. 340).
} 
Ricardo, antigo chefe do DEIP de São Paulo $^{22}$ e então diretor do periódico estadonovista A Manhã. Em Marcha para Oeste (1940), ${ }^{23}$ depois de alertar para o perigo de os escritores nacionais adquirirem certa doença chamada de "infecção cultural", contraída a partir do distanciamento das raízes brasileiras sob o pretexto de que o "espírito" não teria pátria, o poeta de Martim Cererê cita o fundador da ABL como um dos símbolos desta degenerescência:

Sua prosa não é apenas antibrasileira no apuro clássico de um português que se escorrega já se limpa bem de todas as manchas da terra que marcam a raiz dos nossos vocábulos mais toscos e amorosos. Faltam-lhe a cor, a imagem e o ritmo que são sinais psicológicos de toda a linguagem brasileira identificando o homem cheio de rumor primitivo em ligação com a natureza tropical. Sobram-lhe harmonia, polidez, segunda intenção: falta-lhe a seiva gostosa do sentimento. Substituiu ele a desconfiança pela dúvida, pelo ceticismo. A dor brasileira é substituída, também, nos seus livros, por uma dor intelectual sem calor humano e sem sangue. ${ }^{24}$

Se Machado de Assis, apegado a "abstrações" e a modelos importados, não refletiria na língua em que escrevia a "marca psicológica, telúrica, biodemocrática de seu meio", fugindo assim ao "compromisso de sangue" para com a pátria, ${ }^{25}$ outra teria sido a atitude de Euclides da Cunha. Por oposição, Cassiano Ricardo enfatiza que este

\footnotetext{
${ }^{22}$ Departamento Estadual de Imprensa e Propaganda paulista, espécie de "filhote" do DIP, cuja principal atribuição era estender os tentáculos do órgão federal ao Estado de São Paulo.

${ }^{23}$ Em perspectiva teleológica, Marcha para Oeste procurava traçar o itinerário mítico que ia das bandeiras paulistas ao Estado Novo, com o propósito claro de legitimar as ações da ditadura getulista. Nesse processo, privilegiava a imagem, carregada de sentimentalismo, de uma "nação em marcha", em busca de suas próprias origens no interior do país. (LENHARO, Alcir. Sacralização da política. Campinas, SP: Papirus, 1986. p. 53-74).

${ }^{24}$ RICARDO, Cassiano. Marcha para Oeste. Rio de Janeiro: Livraria José Olympio Editora, 1940. p.549.

${ }^{25}$ Centrado na ideia de "nação", Ricardo apresenta uma concepção analógica da relação entre arte e política que lhe permite "discutir problemas estéticos em termos políticos, e problemas políticos em termo estéticos" (MOREIRA, Luiza Franco. Meninos, poetas e heróis - aspectos de Cassiano Ricardo do modernismo ao Estado Novo. São Paulo: Edusp, 2001. p. 79). Nesse sentido, à luz de um nacionalismo estreito, reprova ideologicamente Machado de Assis, mesmo quando aparenta avaliar o estilo do autor de Dom Casmurro de um ponto de vista literário (Idem, p. 83). Ao mesmo tempo, o poeta modernista, de certa maneira, mostra-se tributário de certos postulados críticos de Sílvio Romero, ferrenho opositor de Machado de Assis no século XIX. Pautado pelo racismo científico oitocentista, Romero já teria atentado para a falta de convicção, bem como para o suposto caráter antinatural e não espontâneo do humorismo machadiano, visto como simples cópia de modelos ingleses (GUIMARÃES, Hélio de Seixas. Romero, Araripe, Veríssimo e a recepção crítica do romance machadiano. Estudos Avançados, v. 18, n. 51. São Paulo: USP, 2004. p. 269-298).
} 
pensava "brasileiramente", pois teria deixado de lado o "cosmopolitismo dissolvente", presente nas obras daquele, em proveito da representação de algo novo, a "força original da terra". Ao particularizar seu argumento, o poeta modernista ressalta ainda tanto a perspectiva sociológica como a postura nacionalista empregada pelo autor de $O s$ sertões, que, enquanto escritor, não renegara sua missão, mas, pelo contrário, tê-la-ia encarado sem vacilações, ao deslocar-se ao interior do país e ao eleger tal espaço como tema preferencial de suas obras. ${ }^{26}$

Em certo sentido, ao entender os dois artistas como antípodas, o poeta de Martim Cererê apresentava, analogamente, uma nacionalidade cindida entre litoral e sertão. Machado, sinônimo de falsidade e artificialismo, representaria o primeiro espaço; Euclides, considerado o reanimador da "força original da terra", metonimicamente seria tomado pelo próprio interior do país. Ao mesmo tempo, o contraste entre os dois escritores correspondia à oposição entre dois saberes: respectivamente, a literatura e a sociologia. De acordo com uma categorização estanque e enviesada, entendia-se que Machado se mantinha preso ao universo literário, e Euclides, por outro lado, privilegiava o exame "objetivo" do meio e do homem brasileiros. Assim, num contexto de valorização do cientificismo, no qual a literatura deveria voltar-se para a construção da brasilidade, o romancista de Quincas Borba deveria ser rebaixado, pois negligenciava as raízes rurais do país e adotava um estilo avesso ao "sentimento mais profundo de simpatia humana, de amor a terra, a sua paisagem e a sua gente", ${ }^{27}$ ao passo que o autor de Os sertões se mostrava conectado a uma suposta essência da brasilidade, ao particularizar temas de caráter regional e não urbano.

\footnotetext{
${ }^{26}$ De modo análogo, tal oposição entre Machado e Euclides também estava presente no horizonte crítico de Gilberto Freyre, intelectual que colaborou de modo assíduo com os principais periódicos do DIP. Apesar de divergir conceitualmente de Cassiano Ricardo em muitos aspectos, o autor de Casa-Grande e Senzala (cuja interpretação do país, em sentido oposto ao da "marcha para oeste", tomava o engenho de cana-de-açúcar, e não as bandeiras, como principal agenciador histórico da nação) também considerava Machado uma espécie de "inglês tristonho desgarrado nos trópicos" que se escondia por detrás de "personagens sempre brancos, ioiôs sempre finos", fazendo-se adivinhar no humor de seus romances (FREYRE, Gilberto. Perfil de Euclides e outros perfis. Rio de Janeiro: José Olympio, 1944. p. 22-23). Em oposição, destacava que o dionisíaco Euclides não teria se contentado em ser "nem beletrista, nem subeuropeu", adotando, ao privilegiar o mundo sertanejo, uma postura "construtivamente nacionalista" (FREYRE, Gilberto. Euclides da Cunha - revelador da realidade brasileira. In: CUNHA, Euclides. Obra completa. 2 v. Rio de Janeiro: José Aguilar, v. 1, 1966. p. 24).

${ }^{27}$ Idem, p. 549.
} 
Epistemologicamente, tal perspectiva avaliativa pressupunha que os escritores deveriam travar um contato sensorial, inscrito em suas próprias biografias, com as matérias sertanejas que se propunham a narrar. Mas não parava por aí. Considerava que os homens de letras, além de se colocarem tal como testemunhas ante os fatos a serem ficcionalizados, tinham a missão de realizar o estudo objetivo da "realidade" do país e corroborar o conhecimento e a transformação desta última.

\section{Periódicos getulistas}

Essa cosmovisão manifestada por Cassiano Ricardo era moeda corrente no discurso produzido pelas publicações estadonovistas. Um de seus maiores polos de produção e divulgação era o suplemento "Autores e Livros", do jornal A Manhãa. ${ }^{28}$ Tendo em vista a importância concedida pelo regime de 1937 à literatura no processo de construção e consolidação da identidade nacional, esse caderno dominical procurava recontar a história das letras brasileiras a partir da celebração de uma galeria de vultos do passado, homens representativos das artes e do pensamento do país. ${ }^{29}$ A cada número, uma figura era homenageada. Tal iniciativa incluía a publicação de textos e documentos de autoria desta, bem como artigos biobibliográficos sobre ela, escritos por nomes de destaque no meio intelectual. Entre os festejados, estavam José de Alencar, Machado de Assis, Aluísio Azevedo, Euclides da Cunha, Augusto dos Anjos, Visconde de Taunay, além de um rol extenso de outros autores.

Como indica Velloso, o próprio nome do suplemento já sinalizava para uma concepção de literatura fundada na prevalência do homem sobre a obra. ${ }^{30} \mathrm{~A}$ justaposição das palavras "autores" e "livros", com a precedência da primeira sobre a

\footnotetext{
${ }^{28}$ A partir de 1940, tal periódico passou a fazer parte das Empresas Incorporadas da União, no processo de estatização conduzido pelo Estado Novo. Dirigido por Cassiano Ricardo, o jornal colocava-se como autêntico porta-voz do governo, corroborando a construção do ideário político-ideológico estadonovista.

${ }^{29}$ Como indica o próprio editor do suplemento, Múcio Leão, o plano que "Autores e Livros" adotou foi o de "uma história literária brasileira, organizada em duas partes: uma consistindo em uma antologia da obra de um determinado escritor; a outra, numa seleção crítica referente a este mesmo autor. Publicando semanalmente fascículos que em geral têm 16 páginas, mas que não raro chegam a ter 24 e até 32 páginas - damos por mês três ou quatro capítulos de nossa história literária, com uma amplitude que nenhum tratado sobre o assunto até agora teve" (RELAÇÃO dos artigos publicados até hoje. Autores e Livros. $A$ Manhã, Rio de Janeiro, ano 3, 27 de junho de 1943. p. 305).

${ }^{30}$ VELLOSO, Mônica Pimenta. Literatura como espelho da nação. Estudos Históricos, n. 2, v. 1. Rio de Janeiro, 1988. p. 251.
} 
segunda, aponta para a ideia de que as histórias de vida dos escritores conferiam sentido a suas produções, pressupondo uma correspondência imediata entre umas e outras. Nesse sentido, os volumes eram introduzidos por uma seção intitulada "Notícia", uma espécie de nota histórica, que procurava dar conta do perfil do literato enfocado, privilegiando dados sobre seu nascimento, morte, relações familiares, amizades, trajetória estudantil, entre outras informações. Em seguida, depois da apresentação de uma antologia de escritos da figura homenageada (nos mais variados gêneros - poesia, carta, ensaio, discurso etc.), ganhavam espaço textos críticos. Estes, na sua grande maioria, eram redigidos por companheiros de vida do artista, o que ressaltava o privilégio concedido à sociabilidade intelectual da qual ele participava.

Num momento em que se vinha de comemorar os cem anos de nascimento de Machado de Assis, o tratamento conferido por "Autores e Livros" ao romancista das Memórias póstumas de Brás Cubas foge, de certa maneira, da perspectiva encomiástica esperada. Para além da retórica laudatória habitual, o suplemento reunia artigos com questionamentos sobre a suposta falta de aderência do artista às suas origens pessoais e, coextensivamente, ao protocolo documental, reivindicado pelo Estado no processo de construção da nacionalidade. O fascículo dedicado ao escritor seria um dos únicos, em toda a coleção, a não trazer um relato biográfico introdutório. Referia-se a ele apenas como um "homem estranho, singular, misterioso e perturbador". ${ }^{31}$ Em certo sentido, esse fato pode ser tomado como índice de uma aparente defasagem entre autor e obra atribuída ao romancista pelos editores da publicação. ${ }^{32}$ A corroborar tal hipótese, alguns textos críticos presentes no volume procuravam ressaltar a suposta alienação de Machado tanto em relação aos problemas de seu tempo quanto à sua própria história pessoal, posturas estas que redundariam numa dupla traição: à pátria e a si mesmo.

\footnotetext{
${ }^{31}$ MACHADO de Assis. Autores e Livros. A Manhã, Rio de Janeiro, ano 2, 28 de setembro de 1941. p. 91.

${ }^{32}$ Em "A iconografia de Machado de Assis", também presente nesse mesmo número de "Autores e Livros" (p. 105 e 111), Peregrino Júnior, na ausência de materiais escritos que esclarecessem a trajetória do fundador da ABL, procurou reconstituir-lhe a história pessoal por meio da análise de uma coleção de fotografias. Por detrás de tal iniciativa, subjaz a importância conferida aos dados biográficos, como forma de compreender e justificar a sensibilidade do artista e, por sua vez, o significado de sua obra. Prosseguindo por tal caminho, Peregrino aponta que o sentido da "evolução" tanto física quanto espiritual do obscuro Machado seria o da progressiva aristocratização e braqueamento.
} 
José Lins do Rego estaria entre os detratores de Machado. No texto "Um escritor sem raízes", o romancista paraibano, apesar de realçar os dotes imaginativos do autor de Dom Casmurro, apresenta-o como um escritor aristocrático, desconectado de sua própria história, bem como das aspirações populares. Diante desse aparente problema, afirma que ele ocuparia um lugar à parte em nossas letras:

Machado de Assis ficará sempre à margem de nossa copiosa literatura. Não serviria nunca de modelo, se se quisesse tirar um retrato de seu povo, e mesmo da elite de sua gente. No entanto, há muito do Brasil em sua obra, da boa sociedade dos tempos do segundo império, daquela vida sem estrépitos, daquela mansa e deliciosa vida de família dos educados salões da corte. Mas tudo isto é visto por um inglês cheio do gênio da observação, que ficasse no Brasil pelo gosto de observar. ${ }^{33}$

Portanto, considera que Machado não poderia ser tomado como um exemplo a ser seguido em nosso universo literário, pois, além de realizar um retrato distorcido da vida nacional, orientara-se por uma perspectiva importada de matriz inglesa. Nesse sentido, não só privilegiava o "artificialismo" da vida aristocrática dos salões cariocas, como adotava modelos estranhos para tratar dessa temática. ${ }^{34}$ No entanto, além de observar falhas tanto na eleição dos temas como na forma de abordá-los, José Lins destacava que o autor de Dom Casmurro fora ainda um martirizado prisioneiro dos mestres do vernáculo. Assim, contrapõe o alegado conservadorismo linguístico do romancista à atitude "libertária" de Eça de Queirós. Aquele não tivera a coragem deste, "de pôr-se de encontro a todos os Castilhos que tomassem dores pela gramática. E

\footnotetext{
${ }^{33}$ REGO. José Lins. Um escritor sem raízes. Autores e Livros. A Manhã, Rio de Janeiro, ano 2, 28 set. 1941. p. 99.

${ }^{34}$ Em 1939, Mário de Andrade, cuja colaboração episódica e não sistemática com o Estado Novo deu-se no âmbito do MES de Capanema (LONDRES, Cecília. A invenção do patrimônio e a memória nacional. In: BOMENY, Helena (Org.). Constelação Capanema: intelectuais e política, cit., p. 98), também destacava que Machado não poderia ser tomado como uma figura representativa do "homo brasileiro", pois teria renegado sua classe, sua cor e adotado modelos importados para representar o país, ou seja, fora infiel tanto a si mesmo como a sua pátria. Só não teria naufragado totalmente, velejando por águas tão turvas e perigosas, em virtude de sua genialidade, produzindo, apesar de tudo, um rol de "obras-primas de caráter acadêmico" (ANDRADE, Mário. Aspectos da literatura brasileira. Belo Horizonte: Itatiaia, 2002. p. 124).
} 
violando a sua língua com a força de um fauno, Eça fecundou-a de uma boa porção de impurezas que fizeram um bem sem tamanho 'ao mui rico idioma de Camões'". ${ }^{35}$

Os supostos isolamento e absenteísmo de Machado de Assis foram também referidos em outras cores ao longo da publicação. Barbosa Lima Sobrinho, num texto de caráter predominantemente elogioso, não deixou de expor tais restrições ao tratar, não da obra, mas do próprio escritor:

Toda vez que o mundo lá fora é tumultuoso e violento, ele pega em si mesmo e mete-se no cantinho do gabinete de trabalho, entre os livros de sua afeição. Em todo o vigor da juventude, pode ter os olhos fechados para a Guerra do Paraguai; a Abolição, que desvairou toda a gente, encontra a sua alma resguardada dos furacões [...] O 15 de novembro também não interessou Machado de Assis. A epopeia dos jagunços, que havia de arrancar de Euclides uma sinfonia wagneriana, não consegue, nos registros de A Semana, mais que algumas observações irônicas, amesquinhadoras da tragédia sertaneja. ${ }^{36}$

Para o articulista, Machado viveria numa espécie de "região de neves perpétuas", onde se encontrava a "suprema inteligência". Desse ponto alvo, gélido e afastado, o romancista examinaria com "exatidão e impessoalidade" o "torvelinho humano", sem se entregar às paixões de seu tempo. Com outros propósitos, Sobrinho retoma aqui a oposição entre Euclides e Machado: enquanto o primeiro se deslocara até o campo de batalha sertanejo e compusera uma verdadeira "sinfonia wagneriana", o segundo preferia colocar-se como uma espécie de retratista, minucioso e sutil, das "contradições da alma humana", preterindo "paisagens, descrições e até mesmo ambientes em suas obras". ${ }^{37}$

Em artigo presente no referido número de "Autores e Livros", Jorge de Lima lamenta o fato de Machado nunca ter saído da "penumbra em que vivia", ocultando obstinadamente suas origens raciais. "A humildade de sua filiação de certo traria o mais surpreendente realce, se ele o confessasse, à glória que o escritor já tinha em vida.

\footnotetext{
${ }^{35}$ Ibidem.

${ }^{36}$ LIMA SOBRINHO, Barbosa. Na região das neves perpétuas. Autores e Livros. A Manhã, Rio de Janeiro, ano 2, 28 de setembro de 1941. p. 106.

${ }^{37}$ Ibidem.
} 
Recalcou o pitoresco destas origens coloridas com o sangue que nunca desejou expor como ornato ao seu renome". ${ }^{38}$

Ainda no âmbito do Departamento de Imprensa e Propaganda (DIP), o tratamento dispensado a Machado de Assis em Cultura Política, principal veículo de doutrinação política e ideológica do Estado Novo brasileiro, ${ }^{39}$ não se mostrou diferente daquele observado até aqui. Em editorial intitulado "A ordem política e a evolução intelectual", texto não assinado, mas de autoria de Rosário Fusco, ${ }^{40}$ o suposto absenteísmo do escritor carioca era utilizado para exemplificar a separação que existia entre atividades políticas e intelectuais antes de 1930 (tal como o Estado Novo gostava de enfatizar e a que Getúlio faria referência em seu discurso de posse na $\mathrm{ABL}$ ):

Machado de Assis, a acreditarmos no depoimento de seus biógrafos e críticos, fazia questão de proclamar-se indiferente aos interesses políticos de sua terra. E, realmente, em toda a sua obra considerável, em quantidade e qualidade, não há a menor referência expressa, direta (encontrável em tantos autores de seu tempo) à sociedade que descrevia, considerada como um derivado político da época. ${ }^{41}$

Por mais que o aparente alheamento de Machado possa ser creditado às elites políticas da Primeira República, que, diferentemente do Estado Novo, desprezavam as

\footnotetext{
${ }^{38}$ LIMA, Jorge. A propósito de Machado de Assis. Autores e Livros. A Manhã, Rio de Janeiro, ano 2, 28 de setembro de 1941. p. 98.

${ }^{39}$ Mesclando propósitos culturais e propagandísticos, Cultura Política: revista mensal de estudos brasileiros foi o periódico oficial de maior fôlego e envergadura ao longo da ditadura varguista: circulou mensalmente (com exceção dos números 50 e 51, trimestrais) de março de 1941 a outubro de 1945, em edições de caráter austero e livresco, quase sempre com mais de trezentas páginas. De orientação elitista, voltada preferencialmente aos grupos dominantes, procurava demonstrar, por meio de uma retórica nacionalista, permeada por argumentos de cunho filosófico e científico, o caráter inovador do Estado Novo brasileiro, justificando a suposta superioridade dele frente ao "falido" liberalismo. Nesse processo, a publicação também privilegiava uma visada cultural (daí a importância conferida à literatura e às outras artes) e a retomada, em tom erudito, da história do país como formas de atestar a aparente simbiose entre o regime e a "essência" da nação.

${ }^{40}$ Poeta, ensaísta e romancista mineiro que integrou o grupo modernista de Cataguazes. Espécie de crítico literário oficial do Estado Novo, Fusco foi responsável por textos avulsos e pela seção "História literária do Brasil" da revista Cultura Política. Na mesma publicação, estampou ensaios sobre a figura de Getúlio Vargas. A informação de que o autor de $O$ agressor também redigia os editoriais intitulados "A ordem política e a evolução intelectual" do referido periódico getulista provém de Almir de Andrade. Ver: ANDRADE, Almir. Almir de Andrade (depoimento, 1981). Entrevista concedida à Lúcia Lippi de Oliveira. Rio de Janeiro: FGV/Cpdoc-História Oral, 1985, p. 4

${ }^{41}$ A ORDEM política e a evolução intelectual. Cultura Política, Rio de Janeiro, ano $1, \mathrm{n}^{\circ}$ 1, março de 1941. p.250.
} 
manifestações da "inteligência" e desestimulavam o engajamento intelectual, ${ }^{42}$ Cultura Política praticamente silenciou quanto à obra e à figura do romancista carioca. ${ }^{43}$ Considerando o passado como uma instância "viva", a revista partia do pressuposto de que haveria um "sentido", singular e contínuo, na evolução do povo. ${ }^{44}$ Ao mesmo tempo, empreendia a monumentalização dos agentes capazes de captar essa "essência de brasilidade", privilegiando a noção de que a literatura deveria documentar a história pátria. ${ }^{45}$ Nesse sentido, Machado, "indiferente aos interesses políticos de sua terra", não se enquadrava em tal processo de retomada e edificação do passado imemorial da nação.

Não por acaso, os textos ou a trajetória de Machado de Assis em nenhum momento estiveram presentes nas seções "Páginas do passado brasileiro" e "Intérpretes da vida social brasileira". Estes segmentos de Cultura Política tinham como objetivo reconectar passado e presente, privilegiando costumes, tradições e o estudo das biografias de vultos pátrios, os quais teriam procurado traduzir o imutável "espírito nacional". ${ }^{46}$ Diante de tal ausência, depreende-se que Machado não estaria entre os luminares do passado capazes de representar "as genuínas fontes de inspiração popular" ${ }^{47}$ reivindicadas pelo periódico na construção de um elo entre política e cultura que visava legitimar a ditadura varguista.

Em resumo, percebe-se que a conversão do escritor carioca em vulto nacional, empreendida inicialmente pelo Estado Novo, apresentava caráter circunstancial (por ocasião das comemorações oficiais dos cem anos de nascimento do romancista em 1939), bem como se restringia, sobretudo, à faceta de Machado como "grande operário das letras": um homem de origem popular que chegara à consagração literária por meio

\footnotetext{
${ }^{42}$ Ibidem.

${ }^{43}$ No levantamento feito nos mais de cinquenta números de Cultura Política, detectou-se que apenas dois textos se detiveram no estudo da obra machadiana. Ambos foram publicados na segunda fase da revista, num contexto em que ela perdia parte de sua representatividade. Trata-se de "Machado de Assis e a língua nacional", de Josué Montello (ano 3, n. 32, set. 1943. p. 92-95), e "Vida e poesia de Machado de Assis", de Álvaro Salgado (ano 3, n. 34, nov. 1943. p. 302-308). O primeiro aborda a "claridade" da prosa do autor e o segundo, a trajetória do artista, com destaque para sua produção poética.
}

${ }^{44}$ GOMES, Ângela de Castro. História e historiadores. Rio de Janeiro: FGV, 1999. p. 161.

${ }^{45}$ VELLOSO, Mônica Pimenta. Literatura como espelho da nação, cit., p. 249.

${ }^{46}$ Próprio de um historicismo de tipo romântico, tal conceito era frequentemente utilizado pela revista em torneios argumentativos de cunho propagandístico que procuravam identificar estado e nação. Para mais informações, ver: GOMES, Ângela de Castro. História e historiadores, cit., p. 157-205.

${ }^{47}$ ANDRADE, Almir de. Influência política sobre a evolução social, intelectual e artística do Brasil. Cultura Política, Rio de Janeiro, ano 1, n. 1. p. 228. 
da tenacidade, esforço e dedicação ao trabalho. Em outras palavras, privilegia-se não a obra, mas parte da trajetória do homem, mediante a operosidade de um recorte biográfico pautado pela ótica trabalhista norteadora da ditadura varguista. Contudo, no decorrer dos anos 1940, sob os auspícios do DIP e num contexto de valorização de certo caráter documental da obra de arte, em que o regime tomava a literatura enquanto veículo de registro e testemunho da história pátria, rótulos depreciativos, tais como absenteísmo, evasão e desconexão da vida nacional, voltam a ser impingidos a Machado por intelectuais e periódicos visceralmente atrelados a diferentes esferas do governo ditatorial de Getúlio Vargas.

Referências:

ANDERSON, Benedict. Comunidades imaginadas. São Paulo: Companhia das Letras, 2008.

ANDRADE, Almir de. Influência política sobre a evolução social, intelectual e artística do Brasil. Cultura Política, Rio de Janeiro, ano 1, n. 1.

Almir de Andrade (depoimento, 1981). Entrevista concedida a Lúcia Lippi de Oliveira. Rio de Janeiro: FGV/Cpdoc-História Oral, 1985.

ANDRADE, Mário de. Aspectos da literatura brasileira. Belo Horizonte: Itatiaia, 2002.

A ORDEM política e a evolução intelectual. Cultura Política, Rio de Janeiro, ano 1, n.1, março de 1941.

ASSIS, Machado de. Autores e Livros. A Manhã, Rio de Janeiro, ano 2, 28 de setembro de 1941.

Academia Brasileira de Letras (2). In: HENRIQUES, Claudio Cezar. Atas da Academia Brasileira de Letras: Presidência de Machado de Assis (1896-1908). Rio de Janeiro: ABL, 2001.

AZEVEDO, Fernando. A cultura brasileira. Rio de Janeiro; Brasília: Editora da UFRJ; Editora da UnB, 1996.

BOMENY, Helena. Infidelidades eletivas: intelectuais e política. In: (Org).

Constelação Capanema: intelectuais e política. Rio de Janeiro: Editora FGV, 2001. 
BRASIL. Presidência da República. Coleção das Leis da República dos Estados Unidos do Brasil - Atos do Poder Executivo. 8 v. Rio de Janeiro: Imprensa Nacional, 1939.

CANDIDO, Antonio. Esquema de Machado de Assis. In: Vários escritos. São Paulo; Rio de Janeiro: Duas Cidades; Ouro sobre Azul, 2004.

FERREIRA, Gabriela Manduca. A crítica machadiana durante o Estado Novo. Dissertação (mestrado em Literatura Brasileira), Faculdade de Filosofia, Letras e Ciências Humanas, Universidade de São Paulo. São Paulo, 2011.

FREYRE, Gilberto. Euclides da Cunha - revelador da realidade brasileira. In: CUNHA, Euclides da. Obra completa, v. 1. Rio de Janeiro: José Aguilar, 1966.

GOULART, Silvana. Sob a verdade oficial: ideologia, propaganda e censura no Estado Novo. São Paulo; Brasília: Marco Zero; Programa Nacional do Centenário da República e Bicentenário da Inconfidência Mineira; MCT/CNPq, 1990.

GUIMARÃES, Hélio de Seixas. Romero, Araripe, Veríssimo e a recepção crítica do romance machadiano. Estudos Avançados, v. 18, n. 51. São Paulo: USP, 2004. p. 269298.

O escritor que nos lê. In: ; SACHETTA, Vladimir (Orgs.). Cadernos de Literatura Brasileira, n. 23 e 24. São Paulo: Instituto Moreira Salles, 2008.

"Um apólogo - Machado de Assis" - do escritor singular ao brasileiro exemplar. Machado de Assis em linha n. 8. Rio de Janeiro; São Paulo, dez. 2011. Disponível em: <http://machadodeassis.net/revista/numero08/ rev_num08_artigo06. pdf >. Acesso em: 01.06. 2012.

GOMES, Ângela de Castro. História e historiadores. Rio de Janeiro: FGV, 1999.

JOHNSON, Randal. A dinâmica do campo literário brasileiro (1930-1945). Revista USP, n. 26. São Paulo: USP,1995.

LENHARO, Alcir. Sacralização da política. Campinas, SP: Papirus, 1986.

LIMA, Jorge. A propósito de Machado de Assis. Autores e Livros. A Manhã, Rio de Janeiro, ano 2, 28 de setembro de 1941.

LIMA SOBRINHO, Barbosa. Na região das neves perpétuas. Autores e Livros. A Manhã, Rio de Janeiro, ano 2, 28 de setembro de 1941.

LONDRES, Cecília. A invenção do patrimônio e a memória nacional. In: BOMENY, Helena (Org.). Constelação Capanema: intelectuais e política. Rio de Janeiro: Editora FGV, 2001.

MICELI, Sérgio. Intelectuais à brasileira. São Paulo: Companhia das Letras, 2001.

MOREIRA, Luiza Franco. Meninos, poetas e heróis - aspectos de Cassiano Ricardo do modernismo ao Estado Novo. São Paulo: Edusp, 2001.

PÉCAUT, Daniel. Intelectuais e a política no Brasil. São Paulo: Ática, 1990.

RAMOS, Graciliano. Alexandre e outros heróis. Rio de Janeiro: Record, 2003.

REGO. José Lins. Um escritor sem raízes. Autores e Livros. A Manhã, Rio de Janeiro, ano 2, 28 set. 1941. 
RELAÇÃO dos artigos publicados até hoje. Autores e Livros. A Manhã, Rio de Janeiro, ano 3, 27 de junho de 1943.

RICARDO, Cassiano. Marcha para Oeste. Rio de Janeiro: Livraria José Olympio Editora, 1940.

SOUSA, José Galante de. Fontes para o estudo de Machado de Assis. Rio de Janeiro: MEC / INL, 1958.

VARGAS, Getúlio. A nova política do Brasil. v.6. Rio de Janeiro: Livraria José Olympio Editora, 1940. 1944.

A nova política do Brasil. v.10 Rio de Janeiro: Livraria José Olympio Editora,

VELLOSO, Mônica Pimenta. Literatura como espelho da nação. Estudos Históricos, n. 2, v. 1. Rio de Janeiro, 1988.

Os intelectuais e a política cultural do Estado Novo. In: FERREIRA, Jorge e DELGADO, Lucilia de Almeida Neves (Orgs.). O tempo do nacional-estatismo: do início da década de 1930 ao apogeu do Estado Novo. (O Brasil republicano; v. 2). Rio de Janeiro: Civilização Brasileira, 2007.

Thiago Mio Salla é bacharel em português, linguística e jornalismo pela Universidade de São Paulo; doutor em Comunicação Social e doutorando em Letras pela mesma universidade. Defendeu a tese $O$ fio da navalha: Graciliano Ramos e a revista Cultura Política (2010), e organizou o livro Garranchos: textos inéditos de Graciliano Ramos (2012), publicado pela Editora Record. E-mail: <thiagosalla@usp.br>

Recebido: $14 / 09 / 2012$

Aprovado: 19/11/2012 